\title{
Embryonic Fluid
}

National Cancer Institute

\section{Source}

National Cancer Institute. Embryonic Fluid. NCI Thesaurus. Code C13398.

Fluids surrounding or related to an embryo. 